\title{
腸管カニューレの装着による豚の消化管に おける部分消化汇関する研究
}

\author{
鈴木 健・野本敏郎・小牧 弘・森本 宏 \\ 日本大学農獣医学部, 世田谷区 154
}

(1980．10. 11 受付)

\begin{abstract}
要 約豚の消化管，特に小腸における部分消化を知るために，腸管カニニーレを装着した豚を用い

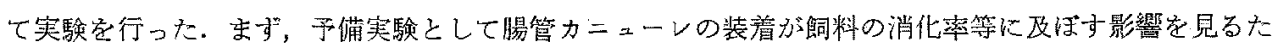
め，カニニーレを供試豚の空腸上部あるい忙回腸末端に 1 力所装着し，指㯲物質（marker）として酸化 クロム $\left(\mathrm{Cr}_{2} \mathrm{O}_{3}\right)$ 添加した飼料を用いて，カニューレ装着前後における消化管内の marker の通過（滞

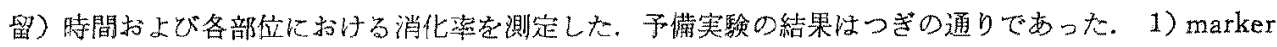
の全消化管内通過時䦩は空腸上部カニューレ装着誐では装着前後においてほとんど差は認められなかっ

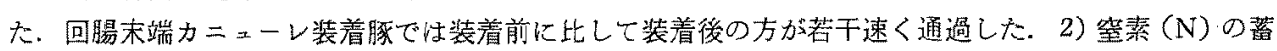

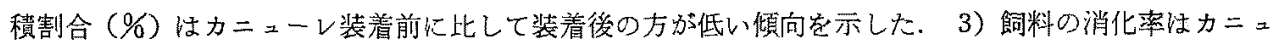

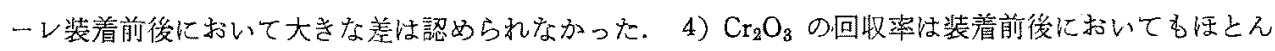
ど差が認められなかった．このように回腸末端カニューレの装着により， markerの全消化管队通過速

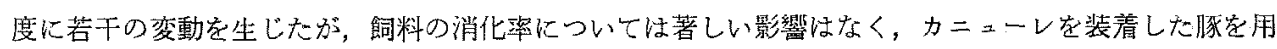

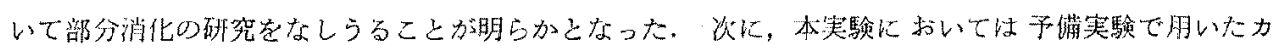
ニューレ装着豚を継続的に朋い，口腔からそれぞれ空腸上部，回腸末端㧍よび肛門までの marker の通

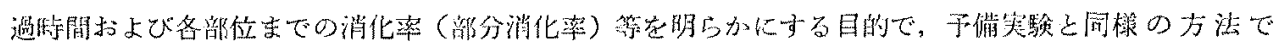

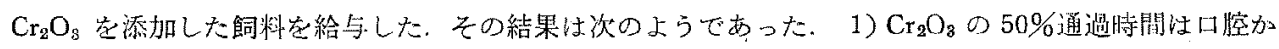
ら空腸上部をでが 40 分，空腸上部から回腸末端をでが 5 㭙間。回腸㾁端から肛門までが 27.4 時間で あった２）有機物の消化管各部位（上部空腸，回腸末端おょび肛門）までの消化率は日腔から空腸上部 までが $7.7 \%$ ，日腔から回腸末端宗でが $69.0 \%$ ，消化管全体で忙 $81.7 \%$ あった，各成分共に小腸 （十二指腸は除く）で大部分消化・吸收され，留・十二指腸ではほとんど吸収がなされていないことが 認められた。

日蓄会報，52(5)：354-361，1981
\end{abstract}

㭬の消化管の各部位の消化・吸収を研究する方法とし て従来，屠殺法が主として用いられている．屠殺法によ れば消化管各部位に斿ける消化率等を同時に測定できる などの利点はあるが，1頭の供試豚について1䁚定值し が得られず，飼料食下後の経時的変化などを知ることが できない欠点があるとされ，また，屠殺によって腸粘膜 絊胞の利離とが，腸内容物の移動などが起るために必 ずしも正確な測定值が 得られないことが指捎されてい 当 ${ }^{2)}$.

近年，豚の尘体にお江名消化管の多部位の消化等空研 究する目的で腸管カニューレ在装着する手法が開発さ れ，この㮔の手法はほとんど全ての面に执いて屠殺法定

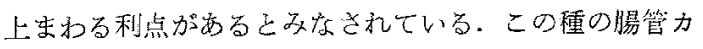

ニューレとしては, 今までにチェーブ型2゙・T字型引・ 還元式型(4) 交換可能型らなどが考案されている。また，

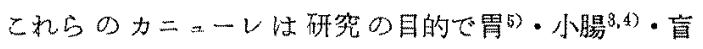
腸2店どの各部位に装着が行われている。

著者は腸管カニューレの装着を行うために装着手術が 容易で预久性の優れたポりエチレン製 T字型カニューレ の改良を行った.カニューレの装着が飼料の消化染に及

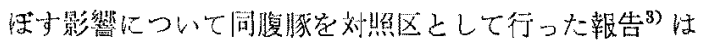
あるが，同一槚において装着前後で比較した竍告は少な いそこでまず予備試験において同一豚老用いてカ二ニ ーレの装着前後におりる飼料の消化率お上び消化管内通 過㭙間等を比較吋るとともに，空腸上部をたは回腸末端 にカニニーレを装着した埸合の装着部位による影響につ 
晹管カニューレ装着豚の部分消化

いても此較穵行ったささらにその結果に基づいて本实駿 として空腸上部・回腸末端に扔る消化率(部分消化率) 定求め，幽門をでの消化率（全消化率）に括りる各部分 消化の貢献程度を明らかにしょうと試みた。

\section{材料および方法}

1. 供試豚と䝭養条件

1) カニューレ装着豚の作成

予備試験での供試豚は体電約 35 50 kg の9 頭の LH 種雄去勢豚を用いて，4頭には小腸上部（胃幽門部より 空腸側へ約 $100 \mathrm{~cm}$ 後方；以下カニューレ1 と䀩称する) および 5 頭には小腸末端（盲回腸部より回腸側へ約 60 $\mathrm{cm}$ 前方；以下カ $=-ー レ 2$ と略称する）にカニニーレ 装着した。

なおっここのカニーレ装着部位を本実駼終了後た㣽も に屠殺解体して測定した結果は，表1のように㧍おむね 所定の位置に装着されていることが認好られた。

Table 1. The length from pylorus to the position of cannula fitted to the small intestine

\begin{tabular}{lrr}
\hline & Length $(\mathrm{m})$ & Index $(\%)$ \\
\hline Small intestine & $13.5 \pm 1.9^{*}$ & \multicolumn{1}{c}{100.0} \\
Position of cannula & & \\
Cannula $1^{11}$ & $1.0 \pm 0.2$ & $7.6 \pm 0.8$ \\
Cannula 23) & $12.9 \pm 1.5$ & $97.6 \pm 0.9$ \\
\hline
\end{tabular}

* Mean value with mean deviation for 4 pigs (cannula 1) and 5 pigs (cannula 2). 1) The pigs fitted intestinal cannula at the upper small intestine (upper jejunum). 2) The pigs fitted intestinal cannula at the terminal small intestine (terminal ileum).

本実験での供試豚は予備実験に供用し，その後体重 $57 \sim 73 \mathrm{~kg}$ に成長したもの継続的に用いた。

これらのカニニーレ装着豚注全頭とも術後 10 日間以 内红回復し，試験期間中に異常忹認められなかった。

カニニーレは古谷ら の $^{3}$ 字型カニューレを参考にポ リェチレン留チェーブ（内径 $8 \mathrm{~mm}$ ，厚さ $3 \mathrm{~mm}$ ) を用い て改良し製作したものである（汹 1)，士な改良点は（1) ポリエチレン製チュープの厚みを厚くし，溶接部在より 強固にした（2）キャップ，ストッバー等の取りはずしを 容易に与尚目的で市ジを切り，そして，キッップ打よび ストッパーに滑り止めの浅い满定つけた（3) ポリエチ レン製ストッパーと表度との閥にシリコン裂のタッショ ンを入れた。 以上のような改良を行なうことにより，強 度・耐久性が高柰り，装着手術がより容易になった。さ
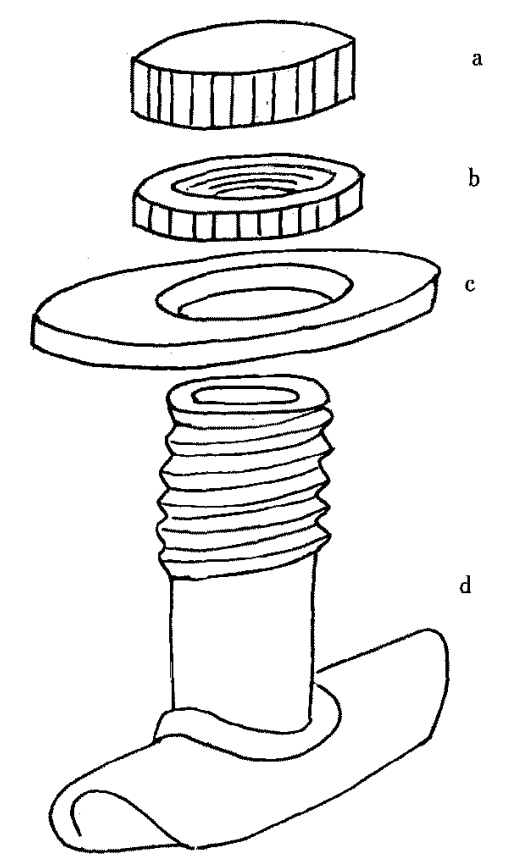

Fig. 1. The model picture of Cannula.

a: Cap. b: Stoper. c: Cushion. d: Cannula.

らに, 装着後からカニューレの自然脱落までの期間がよ り長く持続されるようになった。

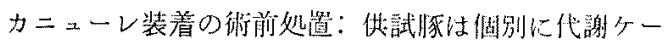
ジに収容して健康状態を確諗し，手術 24 时䦭前に緦食 絶水觉行った。

装着手術の手順：全身森酔削としてペントパルビター ルナトリウム $25 \mathrm{mg} / \mathrm{kg}$ 艺繁部に筋肉内注射した。次 に常法により消毒を行い腹部正中線より左 $2 \mathrm{~cm}$ の部柆 を縦に $20 \mathrm{~cm}$ 压ど切開し, 架腸上部（孯幽門部より空

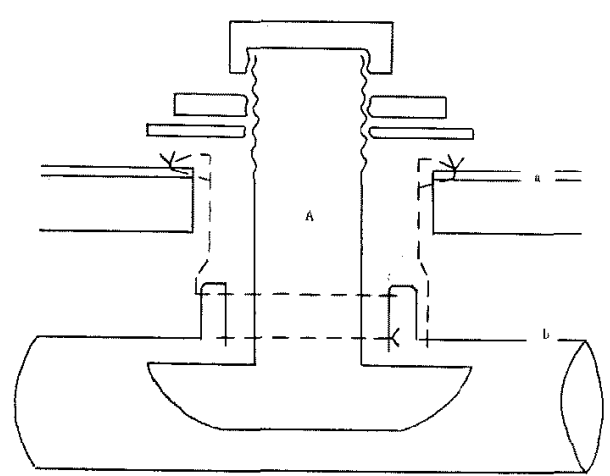

Fig. 2. A cross section of Polyethylen Cannula fitted in small intestine.

A: Cannula. a: Epidermis., b: Intestinal canal. -...: Catgut 


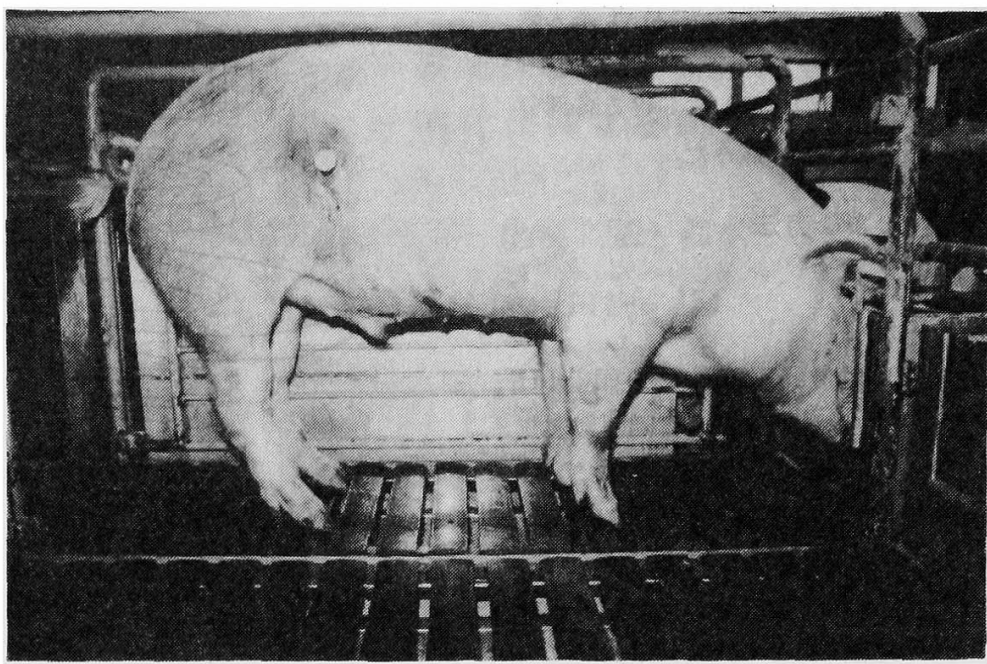

Fig. 3. The pig fitted intestinal Cannula.

腸側へ約 $100 \mathrm{~cm}$ の部位，表 1）および回腸末端（盲回 腸部より回腸側へ約 $60 \mathrm{~cm}$ の部位, 表 1) にカニニーレ を古谷らの方法3) (図 2)により装着し, 左腰部より体外 へ突出させた（図 3)

装着减の術後処置; 術後 24 時間は絶食絶水を行ない, その後飼料を徐々に増量しながら給与したまたぺニ シリン G (90万単位/日) の筋肉内注射を 5 日間連続し て行った。全頭とも術後 10 日以内に回復し, 試験期間 中は異常は認められなかった。供試豚は個別に代謝ケー ジに収容して実験索行った、また, 装着したカニューレ は約 6 ケ月間保持されていた.

2）供試飼料乙飼養条件

予備実験・本実験とも供試飼料の配合割合は表 2 亿示 した、飼料の1日あたり給与量は体重の $4 \%$ 量定等量の 水を用いて練飭とし，1日2回（午前 9:00, 午後 5:00) に分けて給与し, 消化試験用飼料には指標物質 (marker) として酸化クロムを $0.1 \%$ 添加した. 自由飲水とした. 飼育は温度 $21^{\circ} \mathrm{C}$, 湿度 $45 \%$ に自動制御された調温実験 室で行った。

2. marker の通過時間の測定

食慨の食下後から消化管の各部位の通過に要与る時間 から測定した.

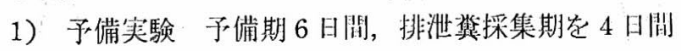
とし,カニッーレの装着前と装着後について行った. 排 泄䨢採集期の第 1 日目の朝の飼料給与直前に給与飼料の 一部（練餉で $200 \mathrm{~g}$ ）に marker として酸化クロム 約 $2 \mathrm{~g}$ を混合して給与し，その後に残りの飼料を与えた. 排泄粪梳 $\mathrm{Cr}_{2} \mathrm{O}_{3}$ 混合飼料採食直後より 3 時間每に採取
Table 2. Ingredients and composition of the experimental diet

\begin{tabular}{|c|c|c|}
\hline Ingredients & & $\%$ \\
\hline Corn & & 37.0 \\
\hline Barly & & 34.7 \\
\hline Soybean meal & & 16.4 \\
\hline Wheat bran & & 8.5 \\
\hline Dicalcium phosphate & & 1.4 \\
\hline Calcium carbonate & & 0.9 \\
\hline Salt & & 0.5 \\
\hline DL-Methionine & & 0.2 \\
\hline L-Lysine & & 0.2 \\
\hline Mineral mixture 1) & & 0.1 \\
\hline Vitamin mixture 2) & & 0.1 \\
\hline \multicolumn{3}{|c|}{ Composition (by analysis) } \\
\hline Moisture & 10. 4 & \\
\hline C. Protein & 17.36 & \\
\hline C. Fat & 2.85 & \\
\hline NFE & 59.38 & \\
\hline C. Fiber & 4.21 & \\
\hline C. Ash & 5.80 & \\
\hline
\end{tabular}

1) $\mathrm{Mn} 6.3 \%, \mathrm{Zn} 9.0 \%, \mathrm{Cu} 1.6 \%, \mathrm{Fe} 13.0 \%$, I $0.1 \%$. 2) Vitamin A $6600,000 \mathrm{IU} / \mathrm{kg}$, Vita$\min \mathrm{D} 1320,000 \mathrm{IU} / \mathrm{kg}$, Vitamin E $20 \mathrm{~g} / \mathrm{kg}$, Vitamin $\mathrm{K}_{3} 5 \mathrm{~g} / \mathrm{kg}$, Vitamin $\mathrm{B}_{1} 1.0 \mathrm{~g} / \mathrm{kg}$, Vita$\min B_{2} 3.8 \mathrm{~g} / \mathrm{kg}$, Vitamin $B_{12} 30.0 \mathrm{mg} / \mathrm{kg}$, Calcium pantothenate $10.0 \mathrm{~g} / \mathrm{kg}$, Nicotinamide $24.5 \mathrm{~g} / \mathrm{kg}$, Choline chloride $330.0 \mathrm{~g} / \mathrm{kg}$. 


\section{䁑篔カニューレ装管豚の部分消化}

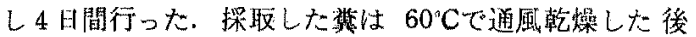
に粉确して分析に供した，各時点の排泄霓中の $\mathrm{Cr}_{2} \mathrm{O}_{3}$ 濃

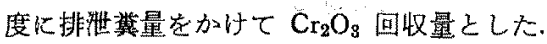

2）本奏験 カニューレ装着の各部位までし全消化管 内の marker の通過時間の測定学行った.

カニューレ装着部位までの marker $の$ 通過時間の則定 は予備期 6 日間，腸内容物採取期間 1 日間之し，腸内容 物採取期間開始日の朝の觡料の給与值前に矛備实験之同 侎の方法で酸化クロム $2 \mathrm{~g}$ を䍡合後給与し食下直後を 0 時間とした，後に残りの給与飼料它給与。しな，一定侍間 後（カニューレ1では， $0.3,0.7,1,2,3,4,5,6,7,9$, $10,11,14,18,24$ 時間後, カ二= $5,6,7,8,9,10,11,14,18,24$ 時間後) k各力= =レより腸内容物をビニール製の採取袋を用いて約 $40 \sim$ $60 \mathrm{ml}$ 採取した。カカニニーレ2からの採取性，回腸末端 における腸内容物の通過が間けつ的であるために採取に 20〜30 分間要する場會もあった。探取した搨内容物は $\mathrm{pH}$ 測定後ニッケルルッボに移し，通風稪燥機を朋い て乾懆後分析に供した、採取した腸内容物の乾物中の $\mathrm{Cr}_{2} \mathrm{O}_{3}$ 沜度老求めた。

marker の全消化管内の通過時間の測定㛎，予倩期 6

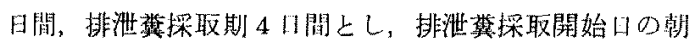
の飼料の給与直前に予備実験と同様の方汒で酸化クロ公 約 $2 \mathrm{~g}$ 混合後給与した。排㴖翼は $\mathrm{Cr}_{2} \mathrm{O}_{3}$ ，混会飼料採 食直後より 3 時間毎に搮取し 4 日間行い，予䚚策験之同 様に処理して 分析用試料とした，各時点の排泄霬中の $\mathrm{Cr}_{2} \mathrm{O}_{3}$ 濃度に排洼基量老加て $\mathrm{Cr}_{2} \mathrm{O}_{3}$ 回收量とした。

3. 消化縣の測定

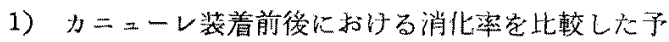
備実験では，予備期 5 日間，本試験期芝 5 日閒として， カニューレの装着前と装着後について消化率を全䔬採震 法にて測定するとともにNの出約について試験した，毎

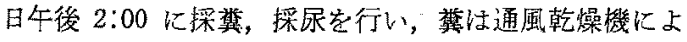
り $60^{\circ} \mathrm{C} 22$ 日間乾燥し, 風乾箱中で 2 日間, 風乾後に粉

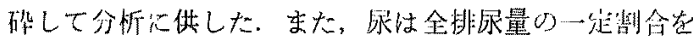
探取して分析に俱した。

2) 消化管の各部位究での飼料の消化率(本英娩)は， 飼料に酸化クロムを $0.1 \%$ 添加し，酸化ク口ム法を用い て測定した。予備期 6 日間，本試駼期4 日間とし，腸内 容物の採取時間は marker 通過時間の測定絬果より, カニューレ 1 で蛙司料採食後 40 分，カ二ニーレ 2 は 5.6 時閫安基準にして約 $200 \sim 300 \mathrm{~m} l$ 採取した。探取した 腸内容物は $-20^{\circ} \mathrm{C}$ で凍結保存し, 凍結乾燥後分析用試料 しした、探取した腸内容物と飼料よりIndex 法により， その部位までの消化率老部分消化率上して測定した。

3) 全消化管での飼料の消化率の测定 (本実験) は, 予備期 6 日間，本試験 6 日間として全鿓採取法により消 化率定測定した，採瓷時間は午後 $2: 00$ とした。採取し

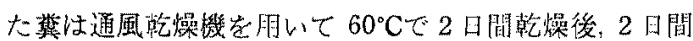
乾燥後，2日閒風乾した後で分析用試料とした.

4) marker の回収試験

カニューV装着前後における酸化クロムの回収試験 は，消化試験に平行して行った。試料子消化試駼㭙に採 取したものと同一のものを朋いた。

\section{5) 試料口分䟟方法}

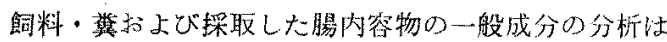

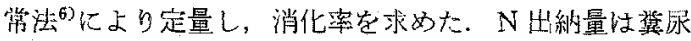
中の全N量をケルダール法6゙にて定量し求めた。酸化ク 口ムの分析㤬過酸化ナトりウム融解法を用いて融解し， クロム酸イオン $\left(\mathrm{CrO}_{4}^{--}\right)$を比色して求めた。

\section{結果および考察}

1) カニューレ装着前後に打ける marker 0 全消化管 内通過時間の比較

カニューレの菇着前と装着後において铝料に混合した 酸化タトムの全消化管内通過時間の測定值安 5\%-95\% retention $\operatorname{method}^{7}$ )用いて解析した（表 3 ），全消化管 内通過時間のカニッーレ装着による影響はカニューレ1

Table 3. Time for $5 \%$ and $95 \%$ excretion of chromic oxide of cannula 1 and cannula 2 and difference between $95 \%$ and $5 \%$ time of before and after operation

\begin{tabular}{|c|c|c|c|c|c|c|}
\hline & \multicolumn{4}{|c|}{ Excretion time (hour) } & \multirow[b]{2}{*}{$95 \%-5 \%$} & \multirow[b]{2}{*}{ time (hour) } \\
\hline & & & & $\%$ & & \\
\hline & B-Ope. & A-Ope. & B-Ope. & A-Ope. & B-Ope. & A-Ope. \\
\hline Cannula $1^{1}$ & $10.3 \pm 3.7$ & $9.1 \pm 3.5$ & $69.3 \pm 3.1$ & $63.5 \pm 10.3$ & $59.0 \pm 5.9$ & $54.4 \pm 9.9$ \\
\hline Cannula $2^{21}$ & $7.1 \pm 2.9^{a}$ & $14.4 \pm 1.6^{\mathrm{a}}$ & $70.4 \pm 1.4$ & $69.9 \pm 2.9$ & $63.3 \pm 3.8^{b}$ & $55.4 \pm 3.3^{b}$ \\
\hline
\end{tabular}

a, b.: $P<0.05$. *: Mean value with mean deviation for 4 pigs (cannula 1 ) and 5 pigs (cannula 2). 1) The pigs fitted intestinal cannula at the upper jejunum. 2) The pigs fitted intestinal cannula at the terminal ileum. B-Ope.: Before operation., A-Ope.: After operation. 
鉿朴・野本・小牧・棵朴

Table 4. Infuence of cannula fitted at intestine on nitrogen balance $g,(\%)$

\begin{tabular}{|c|c|c|c|c|}
\hline & \multicolumn{2}{|c|}{ Cannula $1^{11}$} & \multicolumn{2}{|c|}{ Cannula $2^{2}$} \\
\hline & B-Ope. & A-Ope. & B-Ope. & A-Ope. \\
\hline $\mathrm{N}$-intake & $218.9 \pm 27.7^{*}(100)$ & $323.0 \pm 31.6(100)$ & $226.0 \pm 97.0(100)$ & $316.7 \pm 15.4(100)$ \\
\hline $\mathrm{N}$-in faces & $35.7 \pm 7.1(16)$ & $45.5 \pm 3.0(14)$ & $34.7 \pm 4.0(15)$ & $45.8 \pm 5.0(14)$ \\
\hline $\mathrm{N}$-in urine & $58.7 \pm 9.3(27)$ & $120.1 \pm 11.3(37)$ & $59.2 \pm 11.5(26)$ & $141.4 \pm 28.8(46)$ \\
\hline $\mathrm{N}$-retention & $124.5 \pm 10.5(57)$ & $157.4 \pm 23.9(49)$ & $132.1 \pm 26.3(59)$ & $129.5 \pm 29.0(40)$. \\
\hline
\end{tabular}

*: Mean value with mean deviation for 4 pigs (cannula 1) and 5 pigs (cannuls 2). 1) The pigs fitted intestinal cannula at the upper jejunum. 2) The pigs fitted intestinal cannula at the terminal ileum. B-Ope.: Before operation., A-Ope.: After operation.

Table 5. Influence of Cannula fitted at intestine on the Digestibility of Diet

\begin{tabular}{lcccc}
\hline \hline & \multicolumn{2}{c}{ Cannula 11 } & \multicolumn{2}{c}{ Cannula 22) } \\
\cline { 2 - 3 } \cline { 5 - 5 } & B-Ope. & A-Ope. & B-Ope. & A-Ope. \\
\hline Dry matter & $82.1 \pm 3.1^{*}$ & $84.3 \pm 1.5$ & $84.0 \pm 1.3^{*}$ & $83.8 \pm 2.1$ \\
Crude protein & $83.9 \pm 1.7$ & $85.8 \pm 1.2$ & $83.6 \pm 0.6^{\mathrm{a}}$ & $85.6 \pm 1.4^{\mathrm{a}}$ \\
Crude fat & $75.4 \pm 3.0$ & $80.3 \pm 4.1$ & $70.6 \pm 6.5$ & $75.5 \pm 0.5$ \\
NF E** & $88.7 \pm 1.8$ & $90.2 \pm 1.2$ & $90.5 \pm 1.1$ & $39.8 \pm 2.0$ \\
Crude fiber & $37.2 \pm 13.0$ & $46.4 \pm 5.0$ & $44.6 \pm 0.8$ & $46.4 \pm 5.4$ \\
\hline
\end{tabular}

a.: $\mathrm{P}<0.05$. *: Mean value with mean deviation for 4 pigs (cannula 1) and 5 pigs (cannula 2). **: Nitrogen free extract. 1) The pigs fitted intestinal cannula at the upper jejunum. 2) The pigs fitted intestinal cannula at the terminal ileum. B-Ope.: Before operation., A-Ope.: After operation.

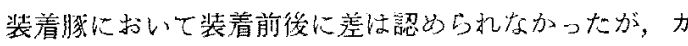
ニューレ2装着豚においでは装曾前に比して装贑捘の力 汃苦于速く通過した。これは，装着手尃による腹膜と腸

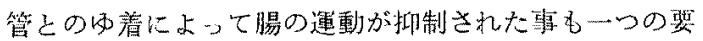
因上考えられる。

2) カニニーレ装着前後に排与空素出約量の比㜞 カニューレの装着前と装着後における穻素出納を表 4 に示した、窒菜の蓄積割合（\%)はカニューレ1あるい はカニューレ2装着豚において，いずれす装着前に比し て装着後の方が低い傾向を示した。

3）力二ニーレ装着前传に打计方飼将の全消化率の此 較

カニューレの装着前と装着㣪に打ける全消化管を通し ての飼料の全消化率芳表 5 亿示した。飼料の消化率は力 ニニーレ1装䒴豚において性装着前後比顕著な差は認め られなかった。カーニーレ装着後の方が粗蛋白質の消化 率が高くなった（P<0，05）が，顕著な差ではなかった。

4) カニューレ装着前後における酸比々口ムの回收率
の比較

カニューレ装着前と装着後に技ける酸化タロムの回收 率を表 6 に示した。酸化クロムの国双率は，カ二ェーレ

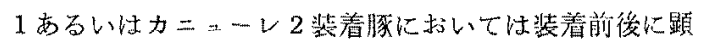
著な差は認められなかった。

Table 6 . Influence of canulation on the recovery of chomic oxide

(\%)

\begin{tabular}{llc}
\hline & \multicolumn{2}{c}{ Cannula fitted operation } \\
\cline { 2 - 3 } & B-Ope. & A-Ope. \\
\hline Cannula $1^{11}$ & $82.7 \pm 7.0^{*}$ & $81.7 \pm 10.6$ \\
Cannula $2^{21}$ & $80.4 \pm 6.9$ & $81.0 \pm 6.5$
\end{tabular}

*: Mean value with mean deviation for 4 pigs (cannula 1) and 5 pigs (cannula 2). 1) The pigs fitted intestinal cannula at the upper jejunum. 2) The pigs fitted intestinal cannula at the terminal ileum. B-Ope.: Before opera tion., A-Ope.: After opeation. 


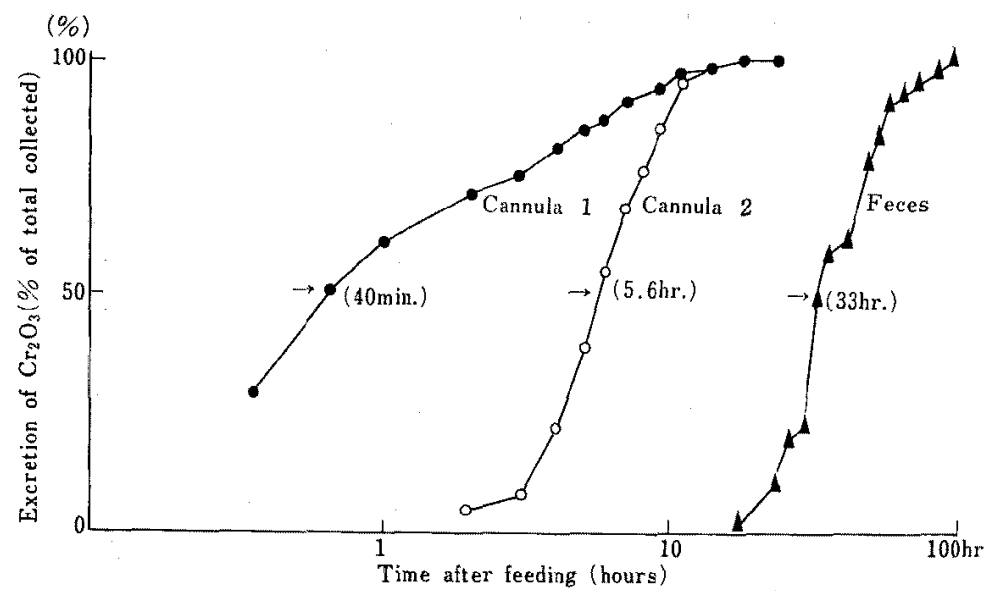

Fig. 4. The passage rate of marker from mouth to upper jejunum, to terminal ileum, and to anus in the pigs.

以上のように，カニッーレ2を装着することにより装 着前後において marker の消化管内通過速度等に若干の 変動が生じたが，全消化率沉ついては著しい影響汭な $く$ カニニーレ装着の豚により消化管の部位による消化 等の研究ができることが明らかとなった。

5）消化管内に扮ける marker の通過時間

消化管内において経時的に測定した酸化クロム濃度 （乾物中）の総和を 100 とした埸合の各特点の酸化ク口 么の通過割合を図 4 に示した，その結果，酸化多口ムの

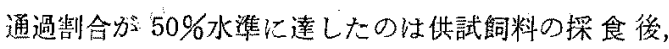
カニューレ1までの通過が約 40 分間，カニニーレ2 での通過が約 5.6 時間，排蕒中（口腔加ら肍門东での通 過）が約 33 时闗であった。ここれらの其験 成績より洘察
すると酸化タロムの通過時間は，口腔から十二指腸まで が約 40 分間, 空腸から回腸までが約 5 洔間, 盲腸から 肛門までが約 27.4 時間となった。

6）飼料の消化管各部分に㧍ける消化

口腔より空腸上部（カニニーレ1），口腔より回腸末端 （カニューレ2）および消化管全体（口腔より肛門）の消 化率を表 7 儿示した。

口腔より空腸上部までの飼料の消化率恃各成分其比低 い值を示した．粗脂肪が負の消化率を示した原因は胆汁 中のメーテル可溶物質（粗脂肪）の混入 $\left.{ }^{8}\right)$ 上び飼料中 に含まれる脂肪含量㤎低いた河に坐じた䛃差ではないか と考党られる。

口腔より回腸末端までの飼料の消化率恃各成分共に漓

Table 7. Effect of partial Digestibility of diet at the site of Cannula and Total digestibility

\begin{tabular}{|c|c|c|c|}
\hline & $\begin{array}{l}\text { At Cannula } 1 \\
\text { digestibility' }\end{array}$ & $\begin{array}{l}\text { At Cannula } 2 \\
\text { digestibility }\end{array}$ & $\begin{array}{c}\text { Total } \\
\text { digestibility }\end{array}$ \\
\hline Organic matter & $7.7 \pm 12.8^{*}$ & $69.0 \pm 3.6$ & $81.7 \pm 1.1$ \\
\hline Crude protein $(\mathrm{N} \times 6.25)$ & $4.6 \pm 23.1$ & $68.9 \pm 5.7$ & $80.5 \pm 0.8$ \\
\hline Crude fat & $-24.0 \pm 52.5$ & $79.8 \pm 7.0$ & $71.5 \pm 5.3$ \\
\hline Nitrogen free extract & $7.1 \pm 14.6$ & $70.7 \pm 3.9$ & $86.5 \pm 0.9$ \\
\hline Crude fiber & $8.5 \pm 11.4$ & $38.2 \pm 9.1$ & $25.5 \pm 8.4$ \\
\hline
\end{tabular}

*: Mean value with mean deviation for 4 pigs (cannula 1) and 5 pigs (cannula 2). ": Digestibility by index methed with chromic oxide as maker. ": Digestibility by total fecal collection method. At cannula 1 digestibility: Digestibility of diet between from mouth to upper jejunum. At cannula 2 digestibility: Digestibility of diet between from mouth to terminal ileum. Total digestibility: Digestibility of diet between from mouth to anus. 
鈴木・野本・小牧・森本

Table 8. The ratio of partial digestion in digestive tract (\%)

\begin{tabular}{lcccc}
\hline & Total- $D^{*}$ & $\begin{array}{c}\text { Stomach } \\
\text { Duodenum }\end{array}$ & $\begin{array}{c}\text { Small } \\
\text { intestine }\end{array}$ & $\begin{array}{c}\text { Large } \\
\text { intestine }\end{array}$ \\
\hline Organic matter & 100 & 9 & 75 & 16 \\
Crude protein & 100 & 6 & 80 & 14 \\
Crude fat & 100 & -33 & 145 & -12 \\
Nitrogen free extract & 100 & 8 & 74 & 18 \\
Crude fiber & 100 & 33 & 117 & -50 \\
\hline
\end{tabular}

*: Digestibility between from mouth to anus in the pigs.

い值を示し，飼料の全体の消化率と比べてる大きな差異 のないことから，回腸末端をでに飼料の各成分共に活と んどが消化・吸収されていることが理解できる。しか し，粗繊維の消化率に杼いては排蕒中に比して回腸末端 までが高い值を示している。これは，豚において粗瀻維 の消化率が変動しやすい事拉よび胃汇おける酸化タロム

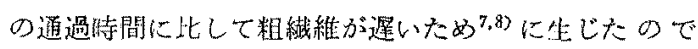
はないかと考光られる。

消化管の全休（全冀採取法）による消化を $100 \%$ とし た場合の消化管各部位において消化される割合は表 8 に 示した、これ飼料の各消化管内における消化怯，霄・ 十二指腸拉よび火腸では，ほとんど消化・吸収が行なわ れていないことを示している。しかし，粗綫維において 注盟・十二指腸および小腸で高い值を示したが，これは 酸化クロムの滞留時間と粗瀻維の滞留時間とが若一異な るために生じたものと考えられる。

以上の結果から，腸管カニューレの適用は豚の消化管 での部分消化等を研究するために非常に便利であり，利 用価值が高いことが確かめられた。 また，先の腸管カ二 ニーレを装着した腺用いて消化管の部分消化率等を測 定した結果は, 主に十二指腸以下の小腸で消化・吸取が 行なわれているということを再確認した。
終りに本研究におけるカニニーレ装着手術について御 指導をいただいた農林水産省畜産試験場 高橋正也博士 に深甚の謝意を表します。

$$
\text { 文献 }
$$

1）熊谷折夫・波烊茂郎・丹羽太告衛門・䇴原二郎編 集, 豩病学一生理 - 疾病 - 飼盖-126-128. 近代出 版. 東京. 1977.

2) Redman, D. R., H. S. Teague., H. K. Henderickx and N. B. KING, J. Anim. Sci., 23: 1032-1035. 1964.

3）古谷修・高橋正也 - 大梀昭一郎，日畜会報，45: 42-44. 1974.

4) Easter, R.A. and T. D. Tanksly, Jr, J. Anim. Sci., 36: 1099-1103. 1973.

5) Decuypere, J. A., I. J. Vervaeke, H. K. HenderickX and N. A. Dierick, J. Anim. Sci., 45: 463-468, 1977.

6）森本 宏監修, 動物栄意試験法. 280-291. 養賢堂. 東京. 1971.

7）古谷 修·高橋 正也，日畜会報，46：630-641, 1975.

8）石川鹿生, 三重大農学報, 24：311-322. 1961. 


\title{
Studies on the Partial Digestion in the Digestive Tract by the Pigs Fitted with Cannula in the Intestine
}

\author{
Takeshi Suzukr, Toshiro Nomoto, Hiroshi KomaKi \\ and Hiroshi Morimoto \\ Laboratory of Animal Nutrition, College of Agriculture and \\ Veterinary Medicine, Nihon Univ., Setagaya-ku 154
}

To investigate the partial digestion in the digestive tract, the experiment were made by the pigs fitted with intestinal cannula at the upper jejunum (cannula 1) and the terminal ileum (cannula 2). The influence of cannula fitted at intestine on digestion was investigated in preliminary experiments, in which pigs fitted with one polyethylene cannula at the upper jejunum or the terminal ileum were used. The rate of passage of diet and partial digestibility were determined by index method using chromic oxide as a marker. Following results were obtained. The passage rate of marker though the all digestive tract by the pig fitted cannula 2 was faster than before fitting. The total nitrogen retention by the pig fitted with cannula at the upper jejunum or the terminal ileum was lower than before fitting. The digestibility of the diet in the pigs fitted at the upper jejunum was similar before and after fitting. In the pigs fitted with cannula at the terminal ileum, the digestibility of crude protein tended to be higher $(P<0.05)$ after fitting, but of no significant difference. By fitting the cannula at the small intestine, the passage rate of diet changed, but had no remarkable influence on digestibility. Then it became clear that the partial digestion could be investigated by using the pig fitted with the cannula in the intestine. The experiments to investigate the passage rate of diets and the partial digestibility at the digestive tract using the pigs fitted with cannula in the intestine were performed. Following results were obtained. The passage rate of the $50 \%$ passage of marker was 40 minites from mouth to the upper jejunum, 5 hours from upper jejunum to the terminal ileum and 27.4 hours from the terminal ileum to the anus. The digestibility of the component of diet was highest between the upper jejunum and the terminal ileum, sugzesting that each component is almost digested and absorbed in the small intestine except duodenum and little digestion and absorption were performed in the stomach, the duodenum and the large intestine.

Jpn. J. Zootech. Sci., 52 (5): $354-361,1981$ 